\title{
Efektifitas Sistem Informasi Akuntansi Dan Manajemen Dalam Pengembangan Ekowisata Monkey Forest Di Desa Adat Padang Tegal
}

\author{
I Nyoman Sutapa* and I Gde Agung Wira Pertama \\ Facultas Ekonomi, Program Studi Manajemen, Universitas Warmadewa, Denpasar, Bali-Indonesia \\ Email: Sutapa05@ymail.com
}

\section{How to cite (in APA style):}

Sutapa, I, N., \& Pertama, I, G, A, W. (2020). Efektifitas Sistem Informasi Akuntansi Dan Manajemen Dalam Pengembangan Ekowisata Monkey Forest Di Desa Adat Padang Tegal. Warmadewa Management and Business Joural, 2 (1), pp.10-16

\begin{abstract}
This study aims to describe the effectiveness of the Accounting Information System (AIS) and Management Information System (SIM) in Padang Adat Village as a source of budgeting information for the development of Ecotourism in the tourist attraction of Ubud's Monkey Key. Data collection is carried out through literature studies, verification and direct observation in the field, interviews and observations. The place of this research is in the traditional village of Padang Tegal and the Ubud Forest tourist attraction. Based on the research results of accounting information systems and management information systems can help the development of Ecotourism in the tourist attraction of Ubud's Monkey Forest through information generated and used as material for decision making by the Padangtegal village through the effectiveness of accounting information systems and the effectiveness of management information systems.
\end{abstract}

Keywords: Effectiveness of Information Systems, Ecotourism Development

\begin{abstract}
Abstrak
Penelitian ini memiliki tujuan mendeskripsikan efektivitas Sistem Informasi Akuntansi (SIA) dan Sistem Informasi Manajemen (SIM) di Desa Adat Padang tegal sebagai sumber informasi pembuatan anggaran untuk pengembangan Ekowisata di objek wisata Monkey Forest Ubud. Pengumpulan data dilakukan melalui studi literatur, verifikasi dan pengamatan langsung di lapangan, wawancara serta observasi. Tempat penelitian ini adalah di desa adat padang tegal dan objek wisata monkey forest Ubud. Berdasarkan hasil penelitian sistem informasi akuntansi dan sistem informasi manajemen dapat membantu pengembangan Ekowisata di objek wisata Monkey Forest Ubud melalui informasi yang dihasilkan dan dijadikan bahan pengambilan keputusan oleh desa pekraman padangtegal melalui efektifitas sistem informasi akuntansi dan efektifitas sistem informasi manajemen.
\end{abstract}

Kata Kunci: Efektifitas Sistem Informasi, Pengembangan Ekowisata

\section{PENDAhULUAN}

Sektor pariwisata dalam perkembangannya dapat dijadikan sebagai sektor yang diandalkan oleh suatu daerah, pariwisata dipandang mampu meyumbang kesejahteraan masyarakat bahkan mampu meningkatkan devisa negara. Kenyataan ini berdampak pada banyaknya negara berlomba - lomba berfokuskan pada sektor pariwisata sesuai dengan potensi yang dimiliki. Bali merupakan salah satu daerah tujuan wisata di Indonesia yang berkembang dan sangat terkenal, mengingat daerah Bali memilki keindahan alam yang mempesona, keunikan budayanya, adat istiadat dan tradisi yang dimiliki oleh masyarakatnya (Suarmana, I. W .R., \& Mahangga, 2014). Tercatat menurut data, jumlah wisatawan asing yang datang ke Bali pada badan pusat statistik dari tahun 2014 sampai dengan 2018 setiap tahunnya mengalami penigkatan yaitu pada tahun 2014 ke 2015 mengalami peningkatan sebesar 6,24\%, pada tahun 2015 ke 2016 meningkat sebesar 23,14\%, 
pada tahun 2016 ke 2017 mengalami peningkatan sebesar 15,62\% dan data terakhir pada tahun 2017 ke tahun 2018 mengalami peningkatan 6,54\%.

Peningkatan jumlah wisatawan asing setiap tahunnya yang datang ke BALI jangan sampai lebih mengutamakan manfaat ekonomi sehingga mengakibatkan terabaikannya pelestarian lingkungan dan terpinggirkannya penduduk lokal. Degradasi lingkungan seperti berkurangnya keragaman hayati terjadi sebagai akibat dari pembangunan berbagai sarana akomodasi, transportasi dan perilaku wisatawan yang kurang ramah terhadap lingkungan. Selain itu pelaku wisata umumnya didominasi oleh pengusaha sedangkan penduduk lokal hanya menjadi pihak yang menjual tanah untuk kepentingan pengusaha dan kemudian terpinggirkan. Berdasarkan hal tersebut maka perlu dikembangkan ekowisata yaitu suatu kegiatan pariwisata yang berwawasan lingkungan dengan mengutamakan aspek konservasi alam, aspek pemberdayaan sosial budaya ekonomi masyarakat lokal serta aspek pembelajaran dan Pendidikan ekowisata.

Berdasarkan pendataan yang dilakukan Disparda Gianyar terhadap 23 destinasi favorit, paling tinggi adalah objek wisata Mandala Suci Wanara Wana atau dikenal dengan nama Monkey Forest Ubud. Kunjungan ke hutan monyet di kampung turis ini mencapai 1.343.152 wisatawan asing sepanjang 2017 dan mengalami peningkatan dari tahun sebelumnya. Rata-rata setiap tahunya tetap terjadi peningkatan kunjungan yang disampaikan oleh Kepala Dinas Pariwisata Gianyar A.A. Bagus Ari Brahmanta (Astraja, 2019). Untuk menjaga lingkungan, budaya dan kesejahteraan masyarakat desa adat padang tegal maka pengelolaan hasil monkey forest ini dikembalikan ke desa adat padang tegal (Nensi, 2019) dalam hal ini pengelolaan desa adat padang tegal menggunakan anggaran yang dibuat dengan pada informasi akuntansi yaitu laporan keuangan dan laporan manajemen yang dibuat oleh manajemen monkey forest Ubud. Untuk itu, maka diperlukan informasi yang tepat waktu, relevan, lengkap, akurat, dapat dipertanggungjawabkan dan dapat digunakan untuk pengambilan keputusan yang tepat dalam pembuatan anggaran dan dalam rangka pengembangan ekowisata agar berjalan sesuai dengan tujuan. Berdasarkan hal tersebut maka peneliti akan melakukan penelitian dengan judul Efektifitas Sistem Informasi Akuntansi Dan Manajemen Dalam Pengembangan Ekowisata Monkey Forest Di Desa Adat Padang Tegal.

Berdasarkan penjelasan latar belakang diatas, maka yang menjadi pertanyaan peneliti dalam penelitian ini adalah sebagai berikut: 1) Bagaimana efektivitas Sistem Informasi Akuntansi (SIA) di Desa Adat Padang tegal sebagai sumber informasi pembuatan anggaran untuk pengembangan Ekowisata di objek wisata Monkey Forest Ubud. 2) Bagaimana efektivitas Sistem Informasi Manajemen (SIM) di Desa Adat Padang tegal sebagai sumber informasi pembuatan anggaran untuk pengembangan Ekowisata di objek wisata Monkey Forest Ubud.

Berdasarkan uraian pada latar belakang permasalahan, maka penelitian memiliki tujuan sebagai berikut; 1) Mengetahui efektivitas Sistem Informasi Akuntansi (SIA) di Desa Adat Padang tegal sebagai sumber informasi pembuatan anggaran untuk pengembangan Ekowisata di objek wisata Monkey Forest Ubud. 2) Mengetahui efektivitas Sistem Informasi Manajemen (SIM) di Desa Adat Padang tegal sebagai sumber informasi pembuatan anggaran untuk pengembangan Ekowisata di objek wisata Monkey Forest Ubud.

\section{TINJAUAN PUSTAKA}

Diana, A., \& Lilis, (2011) menyatakan sistem informasi akuntansi adalah system yang bertujuan untuk mengumpulkan dan memproses data serta melaporkan informasi yang berkaitan dengan transaksi keuangan. Efektivitas sistem informasi akuntansi adalah gambaran sejauh mana 
target dicapai dari suatu kumpulan sumber daya yang diatur untuk memgumpulkan, memproses, dan menyimpan data elektronik, kemudian mengubahnya menjadi informasi yang berguna serta menyediakan laporan formal yang dibutuhkan dengan baik secara kualitas maupun waktu. Pada penelitian ini Efektivitas Sistem Informasi Akuntansi Diukur dengan menggunakan indikator dari penelitian (Sari, R \& Maria, 2009) yang menyatakan indikator sistem informasi akuntansi adalah sistem informasi yang menyediakan informasi (1) tepat waktu, (2) relevan, (3) lengkap, (4) akurat untuk penyelesaian tugas serta (5) menghasilkan informasi untuk pertanggungjawaban dan mendukung dalam pengambilan keputusan.

Efektifitas Sistem Informasi Manajemen suatu sistem berbasis komputer yang menyediakan informasi bagi beberapa pemakai dengan kebutuhan yang serupa. Para pemakai biasanya membentuk suatu entitas organisasi formal/perusahaan/institusi atau subunit dibawahnya. indikator Sistem Informasi Manajemen Menurut McLeod, R. \& George, (2009) adalah 1)Tingkat ketersediaan informasi pada saat diperlukan oleh manajemen/pimpinan; 2) Tingkat memadainya atau kecukupan informasi yang diperlukan oleh manajemen/pimpinan; 3) Tingkat ketepatan waktu penyampaian informasi kepada manajemen/pimpinan pada saat diperlukan; 4) Tingkat akurasi atau akuratnya (tidak salah atau tidak bias) informasi yang tersedia atau yang disampaikan kepada manajemen/pimpinan.

\section{III.METODE}

Penelitian ini menggunakan pendekatan kualitatif untuk dapat menafsirkan fenomena yang terjadi dan dilakukan dengan jalan melibatkan berbagai metode yang ada. Penelitian kualitatif adalah proses analisis data dan informasi secara induktif dengan sifat alamiah (naturalistic) yang apa adanya (Sugiyono, 2017). Dalam penelitian ini dipilih beberapa orang yang dianggap memiliki pengetahuan dan kemampuan dalam pemahaman keadaan setempat dan mampu mengarahkan peneliti kepada informan lain yaitu Manager Monkey Forest dan Bendesa Desa adat Padang Tegal.

Teknik pengumpulan data Meliputi Observasi, dokumentasi, dan wawancara mendalam. Teknik analisis data pada penelitian ini terdapat tiga teknik analisisi data kualitatif yaitu reduksi data, penyajian data dan penarikan kesimpulan.

\section{IV.HASIL DAN PEMBAHASAN Gambaran Umum Monkey Forest Ubud}

Mandala Suci Wenara Wana (Sacred Monkey Forest Sanctuary) - atau lebih dikenal dengan sebutan Monkey Forest Ubud, merupakan daya tarik wisata yang terletak di Desa Pakraman (Adat) Padangtegal, Ubud, Gianyar, Bali. Tempat ini mulai dikembangkan pada tahun 1970 sejalan dengan mulainya wisatawan mancanegara berkunjung ke Ubud. Hutan seluas 12.5 Ha ini merupakan habitat 900 monyet ekor panjang yang dalam istilah ilmiah disebut Macaca fascicularis. Juga tempat tumbuh sekitar 180-an spesies tanaman, seperti: pule, aren, tehep, beringin, mahoni, jati, dan lain-lainnya. Di kawasan Monkey Forest Ubud terdapat 3 pura yang dibangun pada pertengahan abad ke-14, yaitu, Pura Dalem Agung Padangtegal, Pura Prajapati, dan Pura Beji. Pengelolaannya mengacu pada konsep Tri Hita Karana, yaitu menjaga keharmonisan hubungan antara manusia dengan Tuhan, manusia dengan manusia, dan manusia dengan lingkungan.

Pengelolaan Daya tarik wisata Monkey Forest Ubud dikelola oleh masyarakat Desa Pakraman Padangtegal melalui manajemen khusus yang ditunjuk sebagai pengelola. Menyikapi meningkatnya pengunjung dari tahun ke tahun dan untuk memberikan pelayanan yang baik 
kepada pengunjung, dibentuklah Badan Pengelola Wenara Wana Padangtegal (BPWP) pada tahun 1988. Mengetahui potensi yang dimiliki dan perkembangan Monkey Forest Ubud maka BPWP dilikuidasi pada tahun 1999 dan selanjutnya dibentuk manajemen professional dengan nama Manajemen Mandala Suci Wanara Wana.

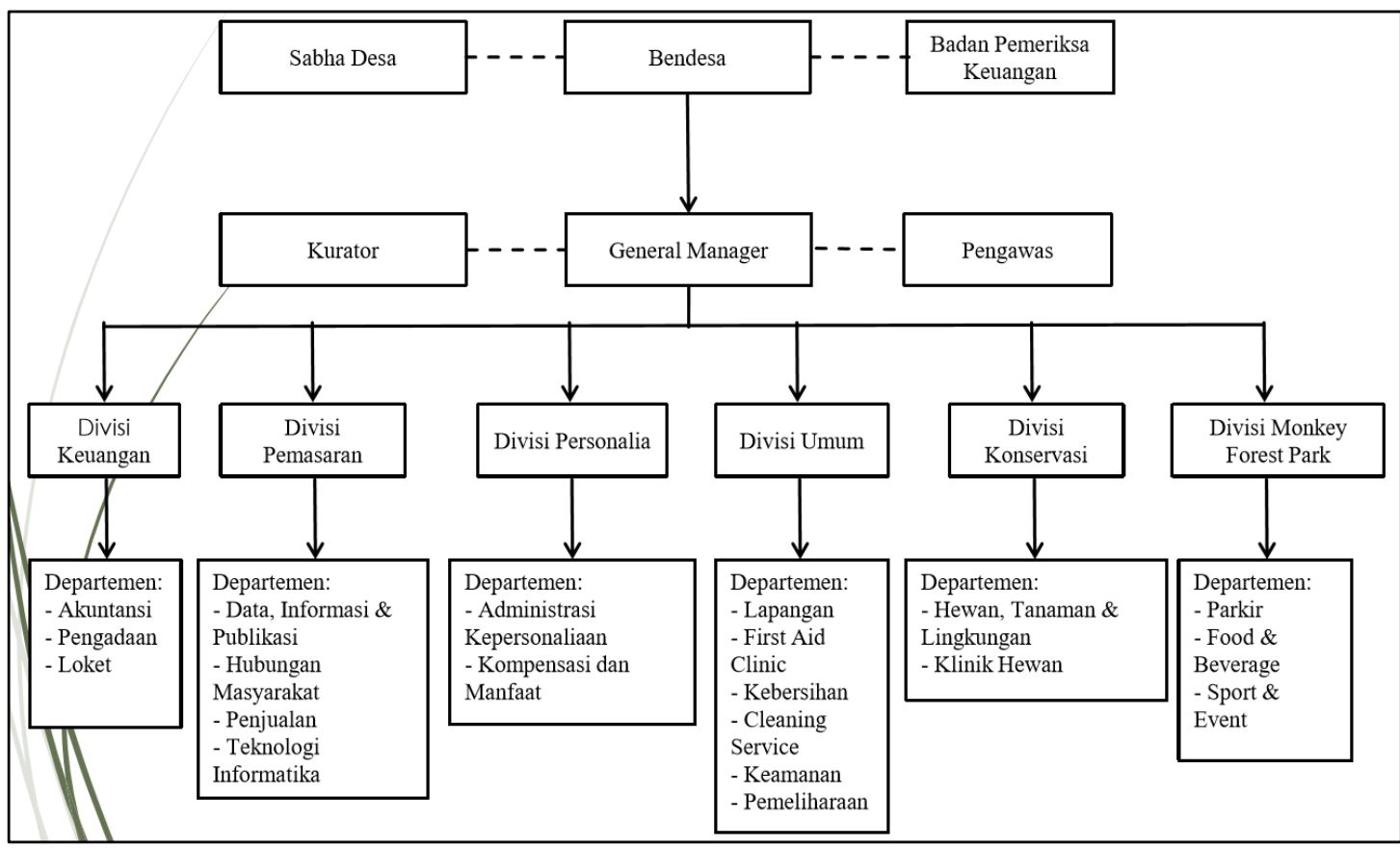

\section{Gambar 1}

Struktur Manajemen Mandala Suci Wanara Wana Sumber : Dokumentasi Kantor desa adat padang tegal 2019

Manajemen Mandala Suci Wenara Wana secara struktural berada di bawah lembaga Desa Pakraman (Adat) Padangtegal artinya, walaupun secara operasional pengelolaan Mandala Suci Wanara Wana dilakukan dengan prinsip-prinsip manajemen profesional tetapi keterlibatan masyarakat adat khususnya dalam hal pengambilan keputusan yang sifatnya strategis, masih sangat dominan. Ini dibuktikan dengan adanya lembaga Kertha Desa, sebagai pengambil keputusan terakhir/tertinggi di bawah Paruman Agung Desa Pakraman, untuk melihat garis herarki pengambilan keputusan maka akan disajikan dalam bentuk struktur organisasi pada gambar 2. Misi dari Mandala Suci Wenara Wana adalah melestarikan kawasan berdasarkan konsep Tri Hita Karana. Tujuan yang ingin dicapai dengan misi ini adalah menjadikan Mandala Suci Wenara Wana sebagai tujuan wisata unggulan internasional yang dapat menciptakan harmoni dan kedamaian (peace and harmony) kepada pengunjung. Sekaligus sebagai paru-paru kota, tempat pelestarian tanaman langka dan yadnya (upacara), dan sebagai laboratorium alam bagi institusi pendidikan. 


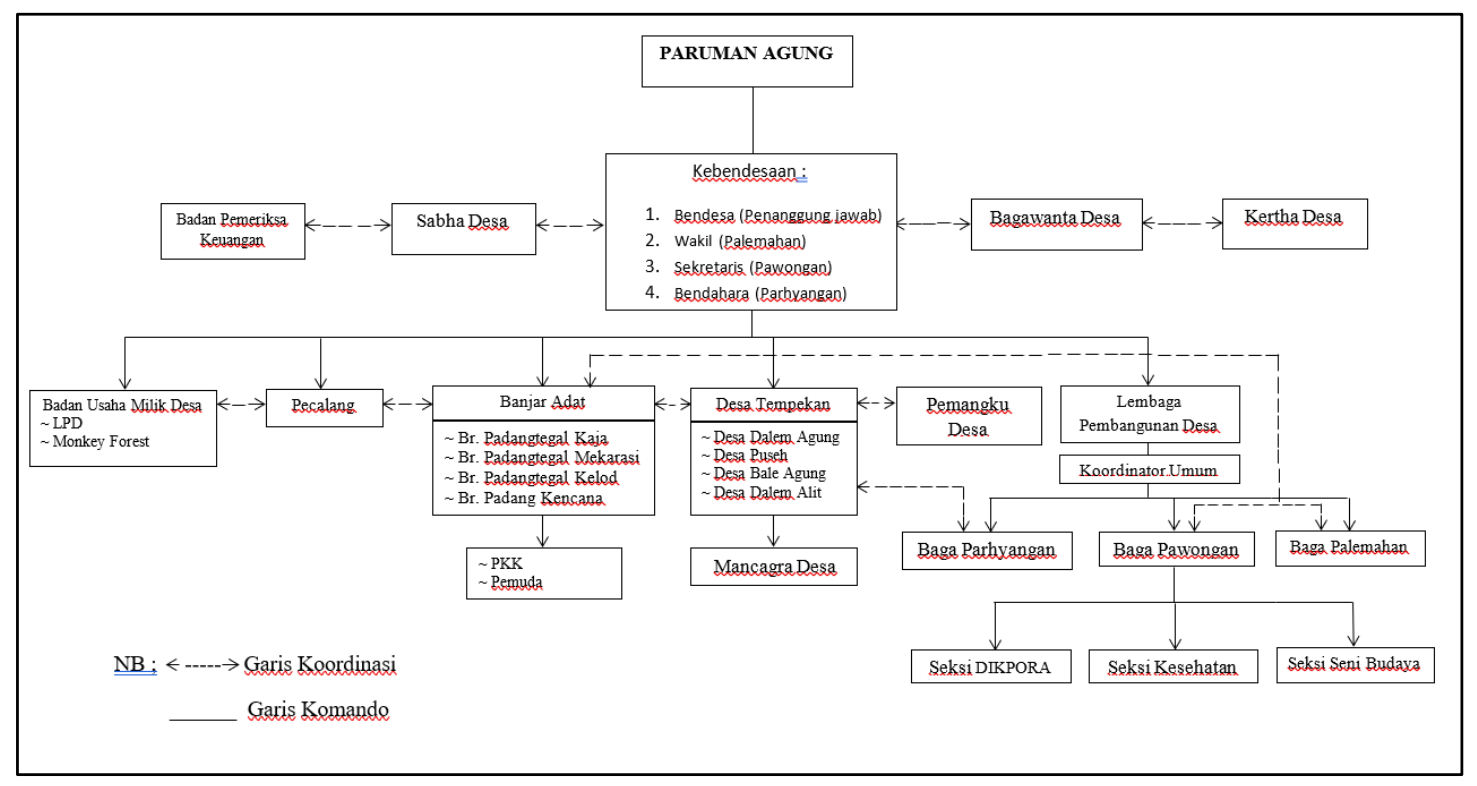

\section{Gambar 2 \\ Struktur Organisasi Desa Adat Padangtegal \\ Sumber : Dokumentasi Kantor desa adat padang tegal 2019}

\section{Penerapan Ekowisata di Objek Wisata Monkey Forest}

Penerapan ekowisata di objek wisata monkey forest akan dijelaskan kedalam tiga kelompok aktivitas yaitu upaya menjaga alam, kebudayaan dan perekonomian masyarakat desa adat padang tegal. Berdasarkan hasil wawancara dengan nensi bagian HRD di objek wisata monkey forest Ubud dan telah dikonfirmasi oleh bendesa adat melalui wawancara langsung bahwa, desa adat padang tegal sudah melakukan aktivitas pelestrian alam, menjaga budaya dan perekonomian desa adat padang tegal. Pelestarian alam yang dilakukan desa adat padang tegal yaitu dengan melakukan penanaman pohon dan perbaikan alam yang rusak. Dalam menjaga kelestarian hutan dan segala isinya di monkey forest ubud pengunjung diwajibkan untuk menghargai rumah dari monyetmonyet ini, seperti pepohonan dan mahkluk hidup lainnya yang terdapat didalam hutan ini.

\section{Bagaimana SIA dan SIM membantu pengembangan Ekowisata di objek wisata Monkey Forest Ubud}

Sistem informasi Akuntansi dan manajemen yang efektif dapat membantu pengembangan ekowisata melalui penyediaan informasi yang dihasilkan. Menurut hasil wawancara peneliti menyimpulkan bahwa sistem informasi akuntansi dapat membantu pengembangan ekowisata di objek wisata monkey forest ubud dikarenakan sistem informasi akuntansi ini digunakan untuk menghasilkan informasi yang nantinya akan dijadikan dasar penyusunan anggaran yang dimana nantinya anggaran tersebut yang dibuat oleh kantor desa melalui paruman agung atau rapat desa akan digunakan salah satunya untuk pengembangan ekowisata. Dana tersebut meliputi $50 \%$ untuk perluasan lahan dan perbaikan lingkungan sedangkan 50\% sisanya akan digunakan untuk dana pembangunan meliputi pembangunan dan perbaikan pura, biaya upacara, beasiswa, kursus , training, dan lain sebagainya untuk kesejahteraan masyarakat desa adat padang tegal. 
Sedangkan sistem informasi manajemen yang menghasilkan informasi mengenai laporan-laporan untuk manajemen seperti informasi perkembangan perusahaan, perkembangan kegiatan objek, penanaman pohon dan lain sebagainya menurut peneliti bisa membantu pengembangan Ekowisata di objek wisata Monkey Forest Ubud hal tersebut dikarenakan informasi yang dihasilkan dari sistem informasi manajemen sebagian besar akan dijadikan dasar pengambilan keputusan manajemen salah satunya adalah perluasan lahan dan perbaikan lingkungan.

\section{Efektivitas Sistem Informasi Akuntansi (SIA) di Desa Adat Padang tegal.}

Berdasarkan hasil wawancara langsung dengan pak bendesa desa adat padang tegal mengenai efektifitas Sistem Informasi Akuntansi di objek wisata monkey forest, dapat disimpulkan bahwa Sistem Informasi Akuntansi objek wisata monkey forest sudah efektif, hal tersebut dikarenakan informasi akuntansi yang dihasilkan oleh sistem informasi akuntansi dalam sebuah Sofeware khusus di objek wisata monkey forest selalu tepat waktu dalam penyampaian informasinya kepada kantor desa. Pengelola menggunakan sofeware akuntansi khusus untuk membantu dalam pembuatan laporan akuntansi seperti laporan laba rugi dan laporan posisi keuangan. Informasi akuntansi yang dihasilkan juga sangat relevan terbukti informasi akuntansi ini selalu digunakan sebagai sumber dalam pengambilan keputusan. Informasi akuntansi ini juga sudah lengkap sesuai dengan kebutuhan pihak kantor desa dan laporan keuangan yang dihasilkan sudah sesuai dengan standar meliputi laporan keuangan, laporan posisi keuangan, buku besar, arus kas serta catatan atas laporan keuangan. Keakuratan informasi yang dihasilkan juga bisa dikatakan sudah akurat karena data buku besar dikunci dengan wewenang khusus, dan apabila terjadi selisih atau kesalahan akan dilakukan pada akhir periode. Dan selama ini belum pernah ditemukan angka yang salah dari temuan BPK (Badan Pengawas Keuangan). informasi ini juga bisa menghasilkan informasi untuk pertanggungjawaban dan mendukung dalam pengambilan keputusan karena informasi yang dihasilkan dijadikan dasar oleh BPK untuk pemeriksaan dan juga sebagai pertanggungjawaban kepada kantor desa dan nantinya akan dijadikan sebagai dasar pengambilan keputusan.

\section{Efektivitas Sistem Informasi Manajemen (SIM) di Desa Adat Padang tegal}

Efektivitas sistem informasi manajemen (SIM) di desa adat padang tegal menurut indikator yang sudah ditentukan mengenai Efektivitas Sistem Informasi Manajemen sudah efektif dikarenakan informasi yang dihasilkan oleh sistem informasi manajemen berbentuk sofeware khusus mampu menghasilkan informasi pada saat diperlukan oleh manajemen/pimpinan seperti perkembangan perusahaan yang melihat tingkat penjualan dari beberapa periode manajemen dengan cepat dapat melihat informasi tersebut karena sudah disediakan oleh sistem. Informasi yang dihasilkan dilihat dari kecukupan informasi yang dihasilkan sudah cukup dikarenakan kantor desa dalam pengambilan keputusan hanya melihat informasi yang dihasilkan oleh sistem tersebut. Informasi manajemen yang dihasilkan dilihat dari ketepatan waktu penyampaian waktu sudah tepat karena laporan manajemen yang sifatnya rutin sudah tersedia sehingga akan dengan sangat mudah disampaikan secara tepat waktu. Informasi manajemen yang dihasilkan dilihat dari keakuratannya dapat dikatakan sudah akurat dikarenakan menurut hasil wawancara selama ini belum pernah ditemukan angka yang salah dari temuan Badan Pemeriksa Keuangan (BPK) internal. 


\section{KESIMPULAN}

Berdasarkan hasil yang sudah dibahas maka dapat disimpulkan bahwa sistem informasi akuntansi dan sistem informasi manajemen dapat membantu pengembangan Ekowisata di objek wisata Monkey Forest Ubud melalui informasi yang dihasilkan dan dijadikan bahan pengambilan keputusan oleh desa pekraman padangtegal. Untuk menghasilkan informasi yang dapat dijadikan pengambilan keputusan maka diperlukan sistem informasi yang efektif. Berdasarkan hasil penelitian ini dapat disimpulkan bahwa Efektifitas sistem informasi akuntansi dan manajemen di desa pekraman padangtegal sudah efektif sehingga dapat dijadikan dasar pengambilan keputusan dan membantu pengembangan Ekowisata di objek wisata Monkey Forest Ubud.

\section{DAFTAR PUSTAKA}

Astraja, M. (2019). 2017, Kunjungan Wisatawan Ke Gianyar Capai 3,8 Juta. http://www.balipost.com/news/2018/04/19/43324/2017,Kunjungan-Wisatawan-keGianyar...html. Diakses tanggal 5 Maret 2019

Diana, A., \& Lilis, S. (2011). Sistem Informasi Akuntansi; Perancangan, Proses, dan Penerapan. Andi.

McLeod, R., \& George, S. (2009). Sistem informasi Manajemen. Pearson Education. Salemba Empat.

Nensi, W. (2019). Wawancara mengenai monkey forest, LPD dan desa adat padang tegal. J1 jembawan, padang tegal kaja.

Sari, R \& Maria, R. (2009). Pengaruh Efektivitas Penggunaan Dan Kepercayaan Terhadap Teknologi Sistem Informasi Akuntansi Terhadap Kinerja Individual Pada Pasar Swalayan Di Kota Denpasar. Jurnal Ilmiah Akuntansi Dan Bisnis, [S.L.], 4. https://ojs.unud.ac.id/index.php/jiab/article/view/2587/1799

Suarmana, I. W .R., \& Mahangga, I. G. A. O. (2014). Bentuk Kontribusi Daya Tarik Wisata Monkey Forest Dalam Mensejahterakan Masyarakat Lokal Di Desa Padang Tegal Kecamatan Ubud. Jurnal Destinasi Pariwisata.

Sugiyono. (2017). Metode Penelitian Kuantitatif, Kualitatif dan R\&D. Alfabeta. 
